INTERNATIONAL BULLETIN OF BACTERIOLOGICAL NOMENCLATURE AND TAXONOMY

Volume 4 April 15, 1954 No. 2 pp. 125-128

\title{
MEMORANDUM ON THE NOMENCLATURE OF THE PNEUMOCOCCUS GROUP
}

\author{
F. Kauffmann and E. Lund \\ Statens Seruminstitut, Copenhagen
}

(Chief: J. $\varnothing_{\text {rskov, M.D.) }}$

Today we have 2 different systems of nomenclature for the designation of serological types or serotypes of pneumococci: The first nomenclature which was published in 1940 by Kauffmann, Mфrch and Schmith, followed Cooper's nomenclature which was retained, but expanded. New types serologically related to one of Cooper's types were gathered into one group; for example Group 7 consists of Types 7, 7A, 7B, and $7 \mathrm{C}$ which have one or more antigens in common. This grouping of related types was undertaken for practical reasons in order to simplify diagnosis and therapy.

In 1941 Walter and co-workers in New York described several new types and accepted the classification of Kauffmann, Mørch and Schmith.

The second nomenclature was published in 1944 by Eddy. She rejected the classification of Kauffmann, M $\phi \mathbf{r c h}$, and Schmith and gave the various types consecutive numbers, regardless of the antigenic structure.

Against the proposal of Eddy the following facts may be advanced:

1) According to the International rules of nomenclature, it is not permissible arbitrarily to alter already published names of bacterial types, for example to call Kauffmann, Morch, and Schmith's Type 7C Type "50". For reasons of priority (1940 against 1944), the first name, "7C", must be retained.

2) Apart from these formal but binding reasons, from a scientific point of view it is preferable when dealing with a type closely related to Cooper's Type 7 to name it "Type $7 \mathrm{C}$ ", rather than give it a new number.

3) In the preparation of diagnostic and therapeutic immune sera it is advisable to gather the related types into group sera. Then, according to circumstances, it will be possible to make a group diagnosis or an exact type diagnosis.

The fact that there is a practical demand for such a grouping is also clear from the fact that Eddy herself puts several types into groups. That being so, why not undertake this 
Diagnostic Antigenic Schema of the Pneumococcus Group (Kauffmann - Mørch - Schmith S chema)

\begin{tabular}{|c|c|c|c|}
\hline Type & Antigens & Type & Antigens \\
\hline 1 & $\overline{1 a}$ & 20 & $\overline{20 a, 20 b}, 7 \mathrm{~g}$ \\
\hline 2 & $2 a$ & 21 & $21 a$ \\
\hline 3 & $3 a$ & 22 & $22 a, 22 b$ \\
\hline 4 & $4 a$ & $22 \mathrm{~A}$ & $22 a, 22 c$ \\
\hline 5 & $5 a$ & 23 & $23 a, 23 b, 18 b$ \\
\hline $6 \mathrm{~A}$ & $6 a, 6 b$ & $23 \mathrm{~A}$ & $23 a, 23 c, 15 a$ \\
\hline $6 B$ & $6 a, 6 c$ & $23 \mathrm{~B}$ & $23 a, 23 b, 23 d$ \\
\hline 7 & $7 \mathrm{a}, 7 \mathrm{~b}$ & 24 & $24 \mathrm{a}, 24 \mathrm{~b}, 24 \mathrm{~d}, 7 \mathrm{~h}$ \\
\hline $7 \mathrm{~A}$ & $7 \mathrm{a}, 7 \mathrm{~b}, 7 \mathrm{c}$ & $24 \mathrm{~A}$ & $24 a, 24 c, 24 d$ \\
\hline $7 \mathrm{~B}$ & $7 \mathrm{a}, 7 \mathrm{~d}, 7 \mathrm{e}, 7 \mathrm{~h}$ & $24 \mathrm{~B}$ & $24 \mathrm{a}, 24 \mathrm{~b}, 24 \mathrm{e}, 7 \mathrm{~h}$ \\
\hline $7 \mathrm{C}$ & $7 \mathrm{a}, 7 \mathrm{~d}, 7 \mathrm{f}, 7 \mathrm{~g}, 7 \mathrm{~h}$ & 25 & $25 a, 25 b$ \\
\hline 8 & $8 \mathrm{a}$ & 27 & $27 a, 27 b$ \\
\hline $9 A$ & $9 a, 9 c, 9 d$ & 28 & $28 \mathrm{a}, 28 \mathrm{~b}, 16 \mathrm{~b}, 23 \mathrm{~d}$ \\
\hline 9L & $9 a, 9 b, 9 c, 9 f$ & $28 \mathrm{~A}$ & $28 \mathrm{a}, 28 \mathrm{c}, 16 \mathrm{~b}, 23 \mathrm{~d}$ \\
\hline $9 N$ & $9 a, 9 b, 9 e$ & 29 & $29 a, 29 b, 13 b$ \\
\hline $9 \mathrm{~V}$ & $9 a, 9 c, 9 d, 9 g$ & 31 & $31 \mathrm{a}, 20 \mathrm{~b}$ \\
\hline 10 & $10 \mathrm{a}, 10 \mathrm{~b}$ & 32 & $32 a, 27 b$ \\
\hline $10 \mathrm{~A}$ & $10 \mathrm{a}, 10 \mathrm{c}, 10 \mathrm{~d}$ & $32 \mathrm{~A}$ & $32 a, 32 b, 27 b$ \\
\hline 11 & $11 \mathrm{a}, 11 \mathrm{~b}, 11 \mathrm{e}$ & 33 & $33 a, 33 b, 33 d$ \\
\hline $11 \mathrm{~A}$ & $11 \mathrm{a}, 11 \mathrm{c}, 11 \mathrm{~d}, 11 \mathrm{e}$ & $33 \mathrm{~A}$ & $33 a, 33 b, 33 d, 20 b$ \\
\hline $11 \mathrm{~B}$ & $11 \mathrm{a}, 11 \mathrm{~b}, 11 \mathrm{f}$ & $33 \mathrm{~B}$ & $33 a, 33 c, 33 d, 33 f$ \\
\hline 12 & $12 \mathrm{a}, 12 \mathrm{~b}$ & $33 \mathrm{C}$ & $33 a, 33 c, 33 e$ \\
\hline 13 & $13 a, 13 b$ & 34 & $34 a, 34 b$ \\
\hline 14 & $14 \mathrm{a}$ & 35 & $35 a, 35 b, 34 b$ \\
\hline 15 & $15 a, 15 b, 15 c, 15 f$ & $35 \mathrm{~A}$ & $35 a, 35 c, 20 b$ \\
\hline $15 \mathrm{~A}$ & $15 \mathrm{a}, 15 \mathrm{c}, 15 \mathrm{~d}, 15 \mathrm{~g}$ & $35 B$ & $35 a, 35 c, 29 b$ \\
\hline $15 B$ & $15 \mathrm{a}, 15 \mathrm{~b}, 15 \mathrm{~d}, 15 \mathrm{e}, 15 \mathrm{~h}$ & $35 \mathrm{C}$ & $35 a, 35 c, 20 b, 42 a$ \\
\hline $15 \mathrm{C}$ & $15 a, 15 d, 15 e$ & 36 & $36 a, 9 e$ \\
\hline 16 & $16 a, 16 b, 11 d$ & 37 & $37 a$ \\
\hline 17 & $17 \mathrm{a}, 17 \mathrm{~b}$ & 38 & $38 a, 25 b$ \\
\hline $17 \mathrm{~A}$ & $17 a, 17 c$ & 39 & $39 a, 10 d$ \\
\hline 18 & $18 a, 18 b, 18 c, 18 f$ & 40 & $40 \mathrm{a}, 7 \mathrm{~g}, 7 \mathrm{~h}$ \\
\hline $18 \mathrm{~A}$ & $18 \mathrm{a}, 18 \mathrm{~b}, 18 \mathrm{~d}$ & 41 & $41 a$ \\
\hline $18 \mathrm{~B}$ & $18 \mathrm{a}, 18 \mathrm{~b}, 18 \mathrm{e}, 18 \mathrm{~g}$ & 42 & $42 a, 20 b, 35 c$ \\
\hline $18 \mathrm{C}$ & $18 \mathrm{a}, 18 \mathrm{~b}, 18 \mathrm{c}, 18 \mathrm{e}$ & 43 & $43 a$ \\
\hline 19 & $19 a, 19 b, 19 d$ & 44 & $44 a, 44 b, 12 b$ \\
\hline $19 A$ & $19 a, 19 c, 19 d$ & 45 & $45 a$ \\
\hline $\begin{array}{l}19 \mathrm{~B} \\
19 \mathrm{C}\end{array}$ & $\begin{array}{l}19 a, 19 c, 19 e, 7 h \\
19 a, 19 c, 19 f, 7 h\end{array}$ & 46 & $46 a, 44 b$ \\
\hline
\end{tabular}


B ACTERIOLOGICAL NOMENCLATURE AND TAXONOMY

grouping according to Kauffmann, Mørch, and Schmith's antigenic schema, which shows the natural relationships of the various types?

4) Experience extending over several years proved the suitability of the Danish nomenclature. The division into groups is not artificial but corresponds to the natural conditions. Whereas some types like 1 and 2, show a pronounced serological specificity, others, such as the types in Group 7, have strongly developed common capsular antigens and thus form a natural group.

Another argument in support of subdividing the pneumococci into groups of serologically related types is to be found in the fact that there are antigens common to certain groups of pneumococci and other kinds of bacteria.

For example, Kauffmann and Langvad-Nielsen demonstrated antigens common to one type of Salmonella (S.kirkee) and all the types in pneumococcus Group 35. Similarly, Mørch found antigens common to two strains of non-haemolytic streptococci and the pneumococcus Groups 19 and 24 . Furthermore, Mørch and Knipschildt demonstrated antigens common to a coli strain and pneumococcus Group 9.

5) The State Serum Institute, Copenhagen, is today the only institute manufacturing and distributing all diagnostic pneumococcus sera. Since January 1, 1942, the Danish sera have been supplied to institutes in most of the countries of Europe. These pneumococcus sera are designated by the Danish nomenclature, which is therefore followed in these countries and the results obtained with these sera are reported in the literature. Strains of all types of pneumococi are also supplied to many institutions.

It will therefore cause a great deal of confusion if this nomenclature, generally employed as it is in Europe, were now to be altered.

For these reasons we decline to alter the nomenclature we published in 1940, which maintains Cooper's nomenclature and which in principle has been accepted by Walter and coworkers.

We therefore suggest that Kauffmann, Mørch and Schmith's nomenclature should receive International recognition. 


\section{REFERENCES}

Eddy, B. E. Nomenclature of pneumococcic types. U.S. Public Health Reports 59:449. 1944. - Cross reactions between the several pneumococcic types and their significance in the preparation of polyvalent antiserum. Ibid. 59:485. 1944.

- A simplified procedure for detecting cross reactions

in diagnostic antipneumococcic serum. Ibid. 59:1041. 1944.

Kauffmann, F., E. Mørch, and K. Schmith. On the serology of the pneumococcus group. J. Immunol. 39:397. 1940.

Lund, E. Four new pneumococcus types. Acta Path. et Microbiol. 27:720. 1950.

Walter, A.W., V. Quevin, M.W. Beattie, H.Y. Cotler, and H. B. Bucca. Extension of the separation of types among the pneumococci: Description of 17 types in addition to Types 1 to 32 (Cooper). J. Immunol. 41:279. 1941. 